\title{
The Kurdish Democratic Union Party and the Kurdish People's Protection Units are partners or potential enemies of Turkey?
}

\author{
Dr. Mohamed Aziz Abdul-Hassan Al-Bayati \\ Assistant Professor, College of Political Science, University of Baghdad Al- Jadriya Complex, Baghdad, Iraq
}

Received 10 March 2019, Accepted 12 May 2019, Available online 14 May 2019, Vol.7 (May/June 2019 issue)

\begin{abstract}
Is it possible that the United States of America and the Kurdistan region of Iraq can bring together views and facilitate the containment and minimization of the dangers of the Democratic Union Party and the People's Protection Units on the Turkish national security? As a hypothetical common ground was found between Turkey and the Democratic Union Party, what are the demands of the parties militarily and politically?
\end{abstract}

Keywords: Kurdish Democratic Union Party Kurdish People's Protection Units partners potential enemiesTurkey

\section{Introduction}

A vision for the future of the possibility of the success of Turkish soft power by moving Kurdish forces in the south towards tenderness instead of moving northward towards the Turkish border.

Turkish President Erdogan played an important role in shaping the lines of foreign policy transformation. As a statesman who played an important role in leading Turkish foreign policy

And the consolidation of Turkish public opinion after the impact of the elite generals of the National Security Council in the manufacture of this policy, which did not take the Turkish public opinion in mind.

\section{Mr. Erdogan said}

"Turkey is not a modern state, nor a state without roots, nor is it a small or weak state, and no one can try to feel Turkey's pulse and patience

Just as Turkey's friends have a strong friendship, our enemies face strong hostility at the same time.

And that Turkey's geographical location required it to play an active regional role in the Middle East and the Balkans.

"We will not allow ethnic or religious nationalism, and we are against all forms of discrimination, and we believe that strong Turkey is the one that embraces all identities "Turkey is not a country that sets its own agenda, but a country that sets its own agenda and contributes to

*Corresponding author's ORCID ID: 0000-0000-0000-0000 DOI: https://doi.org/10.14741/ijmcr/v.7.3.10 determining the direction of the events surrounding it," Erdogan said.

Turkey has become a country of great weight and influence, and a founding player of the regional and international system. This is no longer an option but a historical inevitability

At the end of 2012, the first battles broke out in northern Syria, a region with a Kurdish majority bordering the Turkish border, when many armed opposition crossed the Turkish border and attacked the forces of the Syrian regime, which was based in the city of Ras al-Ain. (YPG), the military wing of the Kurdish Democratic Union Party

2.The Democratic Union Party still considers itself part of the PKK and has so far expressed its sympathy for and concern over Ocalan's plight, as happened at the September 2016 Brussels conference

The fighters of the Democratic Union Party and the PKK are moving between the two sides.

The leadership of the Kurdistan Workers' Party (PKK), retreating in the remote Kandil mountains close to the Kurdistan Regional Government borders with Iran and Turkey, still has some influence over the decisions of the Democratic Union Party.

And the emergence of the Democratic Union Party and the People's Protection Units near the western Euphrates and the southern border of Turkey

The statesman, Mr. Erdogan, realized that a geopolitical and strategic reality might be formed on the southern border of Turkey, and this situation threatened Turkey's national security from three directions

Threats from the South: The Democratic Union Party, the People's Protection Units, a Kurdish Syrian group, and the former ISIS organization, as ISIS's influence 302 |Int. J. of Multidisciplinary and Current research, Vol.7 (May/June 2019) 
diminished after the liberation of Mosul, Anbar, large parts of the Iraqi and Syrian Arab territories and its end after the Battle of the Syrian Baguoz and Syrian President Bashar al-Assad.

\section{The following legitimate questions may arise}

How can the Turkish military strategy deal with the danger of the emergence of the Kurdish Democratic Union Party and the Kurdish People's Protection Units near the Turkish southern border with potential partners or enemies in the foreseeable future?

Is there a realistic chance of using Turkish soft power for the possibility of the success of Turkish soft power by moving the Kurdish forces in the south towards tenderness instead of moving north towards the Turkish border?

Is it possible to agree on the pledge of the Democratic Union Party and American guarantees that:

- The Democratic Union Party pledged to refrain from sending weapons to Turkey and to pledge to avoid allowing PKK fighters to enter Turkey through its territory.

- The leaders of the "Democratic Union Party" in cooperation with the Syrian political opposition to isolate Syrian President Bashar al-Assad and pledge to strengthen relations with the Kurdistan region of Iraq and coordination of positions between them, security, political and military in the regions of Qandil and Sinjar in preparation for the entry of unconditional talks and mediation between the United Union Democratic and People's Protection Units and Ankara?

The central question remains: Can a close relationship with the Democratic Unionist Party and the People's Protection Units give Ankara and Washington some leverage over Kurdish armed groups in Syria's Kurdistan?

\section{Is it possible to make the following?}

First, the use of this fact, confirmed by Turkish and US intelligence sources, is that the border areas controlled by the Democratic Union Party are those where weapons, drugs and money are not smuggled into Turkey.

Second, to use the signs of good faith tells that the Democratic Union Party has committed to its 2012 agreement to avoid attacks on Turkey, specifically to protect its own region within Syria instead of transferring the Kurdish conflict across the border.

If both the Democratic Union Party and the People's Protection Units are potential partners of Turkey - not a threat - to secure their common border with the PKK or ISIS or to coordinate the overthrow of Bashar Assad's regime or to contribute to curbing influence Russian and Iranian in Syria and finally can contribute to increase the convergence with the Kurdistan region of Iraq?
Is it possible that the Democratic Union Party will cut off or at least freeze its relations with the PKK in exchange for expertise and intelligence information and stop the logistical and military support between them (which is unlikely in the near or medium term?

And that he would never break his ties with the PKK, but he might be persuaded to reduce tensions with Turkey and respect Ankara's interests?

Such an outcome would help to focus the efforts of all Turkish and US parties, the Democratic Union parties and its military wing, the People's Protection Units and the Kurdistan Region of Iraq

\section{Towards two objectives}

First: To assist the United States in ending the ISIS file.

Second: Coordination with the Syrian armed opposition factions to isolate Syrian President Bashar al-Assad.

If agreement is reached on these two matters: The United States may undertake to provide the People's Protection Units - the armed wing of the Syrian Democratic Union Party - with heavy weapons, including anti-tank and antiaircraft rocket launchers.

The People's Protection Units helped restore control of the land held by ISIS in Iraq and Syria

The outcome of the answer to these questions will help to understand the justification for the entry of the Erdogan government in serious negotiations with the Democratic Union Party and the military wing of the protection units of the people on the one hand, and that the motive behind Turkey's policy in Syria will be latent tactical opportunities instead of strategic considerations?

\section{Conclusions}

It is now possible to determine the justifications and motives that led Turkish President Erdogan as a statesman to enter into serious negotiations with the Democratic Union Party and the People's Protection Units and with US mediation and in coordination with the Kurdistan Regional Government of Iraq as follows:

First: Turkey is not prepared to threaten its national security by the continued existence of Kurdish armed groups on its borders supported by the US ?

At the same time, Turkey's interests in Syria cannot be ignored, its standards are not ignored in its national security, and the lack of coordination between Turkey and the United States would be detrimental to the interests of both countries?

Secondly, Sinjar for the PKK is much closer to Rugaja, which allows the PKK to have excellent communication and logistics lines with the territory under the control of the People's Protection Units.

And that Turkey is seriously trying to cut the way for the PKK to form military bases and command and control headquarters and infrastructure in Sinjar on the one 
hand, and cut lines of communication and support and logistics coordination and exchange of intelligence between the PKK and the protection of the people in northern Syria, on the other hand.

However, the mountainous region of Sinjar provides the PKK with the advantage of the rugged terrain most suited to its traditional conventional war tactics against Turkey. The northern side of Mount Sinjar provides natural fortifications similar to the strategic fortifications of the PKK in the Qandil Mountains, The Turkish armed forces have realized the importance of this and will therefore try in various ways to prevent the formation of the second Kandil mountain in Sinjar threatening Turkey's national security?

The Turkish military leadership realized that it was forced to accept the arming by the United States of America of the People's Protection Units, the armed wing of the Democratic Union Party, with heavy weapons With its legitimate concerns that these heavy weapons would be transferred to the PKK

Although the heavy weapons enabled the People's Protection Units to take over more land under the authority of the ISIS organization, which actually took place after the takeover of many of the ISIS-controlled areas by the Syrian Democratic Forces, the last of which was the battle of the Syrian Baguoz

The abandonment of the "Democratic Unionist Party" could push Syrian Kurds toward Russia, jeopardizing the interests of both Washington and Ankara.

Accordingly, while Washington should consider not supplying heavy weapons to the Democratic Union Party, Turkey needs to build good relations with the group and reconciliation with the Democratic Union Party and the People's Protection Units.
Cannot Ankara ignore the Kurds in the Syrian Kurdistan or else the alternative will be the Democratic Union Party and the People Protection Units towards Russia and Bashar Assad's regime?

Russia's support for the Democratic Union Party and the PKK will put these two groups in the position of Hezbollah for Israel?

Perhaps the right mix of catalysts from Washington and Ankara is urging the Democratic Union Party to become a trusted ally for both the Turks and the Americans?

\section{References}

[1]. After Afrin Turkey cannot continue to play 'Kurdish card' in Roj - Rudaw

[2]. www.rudaw.net/english/analysis/11032019

[3]. Analysts say US bounty for PKK leaders won't stop ... Kurdistan 24

[4]. www.kurdistan24.net/en/news/dea38b61-b78d-4b10aa45-4bfe47f21b5b

[5]. Can Syria's Kurds keep control of their territory? - The precarious state ...

[6]. https://www.economist.com/middle.../can-syrias-kurdskeep-control-of-their-territory

[7]. How to Stop the War Between Turkey and the Syrian Kurds - The ...

[8]. https://www.washingtoninstitute.org/.../how-to-stop-thewar-between-turkey-and-the-s ...

[9]. Turkey, Syria, and the United States: Quagmires Are Us Council on ...

[10]. https://www.cfr.org/blog/turkey-syria-and-united-statesquagmires-are-us

[11]. The Impact of the Syrian War on Kurdish Politics ... Chatham House

[12]. https://www.chathamhouse.org/sites/default/.../2015072 3SyriaKurdsGunesLowe.pdf 